\title{
Pulmonary Vascular Resistance (PVR) Late after Heart Transplant in Patients with Higher Preoperative Pulmonary Hypertension and Influence on Survival-A Study from India
}

\author{
Ratnagiri Ravi Kumar* and Prabhat Dutta \\ Department of Heart and Lung Transplantation, Gleneagles Global Hospital Chennai, India
}

Submission: January 18, 2019; Published: February 26, 2019

*Corresponding author: R Ravi Kumar, Department of Heart and Lung Transplantation. Gleneagles Global Hospital, 439, Cheran Nagar, Chennai, India

Keywords: Pulmonary vascular resistance; Pulmonary hypertension; Pulmonary compliance; Pulmonary heamodynamic; Heart transplantation; Right heart failure

\section{Introduction}

The Impact of Higher pre-operative Pulmonary vascular resistance and persistent Post-operative Pulmonary Arterial Hypertension (PAH) or pulmonary Compliance (Pca) on the Early Mortality or late Morbidity and Survival after a Successful Heart Transplantation is not well defined.

\section{Methods}

We studied 12 Patients who underwent Successful heart Transplant with High Pre-operative Pulmonary pressures defined as PA systolic pressure more than $50 \mathrm{~mm} \mathrm{Hg}$ but with Transpulmonary Gradient less than $16 \mathrm{~mm}$ hg after Vasodilator testing, for analysis of Pulmonary heamodynamic parameters like Pulmonary Vascular Resistance, (PVR) and Pulmonary Compliance(Pca) early (one month) and one Year after Heart Transplantation along with Survival at 6 months and one year. These 12 patients were statistically compared with 25 patients who had preoperative PA systolic pressures less than $50 \mathrm{~mm} \mathrm{hg}$ 11 of above patients were on both Sildenefil and Ambrisentan for PAH [1].

\section{Results}

Age range was, Females $=1$, Males $=17$, Mean CPB time in These high PAH patients $=140$ minutes, Mean Preoperative PA Systolic pressures $=58.80 \mathrm{~mm}$ (78-50 $\mathrm{mm}$ hg), Mean Pre-operative PVR = 4.1 wood units, Mean preoperative PA compliance $=1.02$ (1.470.79). At three Months Mean PA Sytolic pressures $=38 \mathrm{MM} \mathrm{HG}$, mean PVR $=3.5 \mathrm{WU}$, Mean PA compliance $=0.9$. Of the 8 patients who completed 1 year of study, Mean PA systolic pressures $=35$ MM HG, mean PVR $=3.5$, Mean PA compliance $=0.85$ UNITS. $87 \%$ of the Total patients were alive at 1 year. $93 \%$ of the High PAH group were alive at 6 months after Transplantation [2,3]. There was No incidence of Clinical RV failure after Heart Transplant. There was 1 early Mortality related to Sepsis. Kaplan Meier analysis showed No difference in event free survival between the High PVR and Normal PVR group (p value $=0.7$; NS) [4,5] Figure 1.

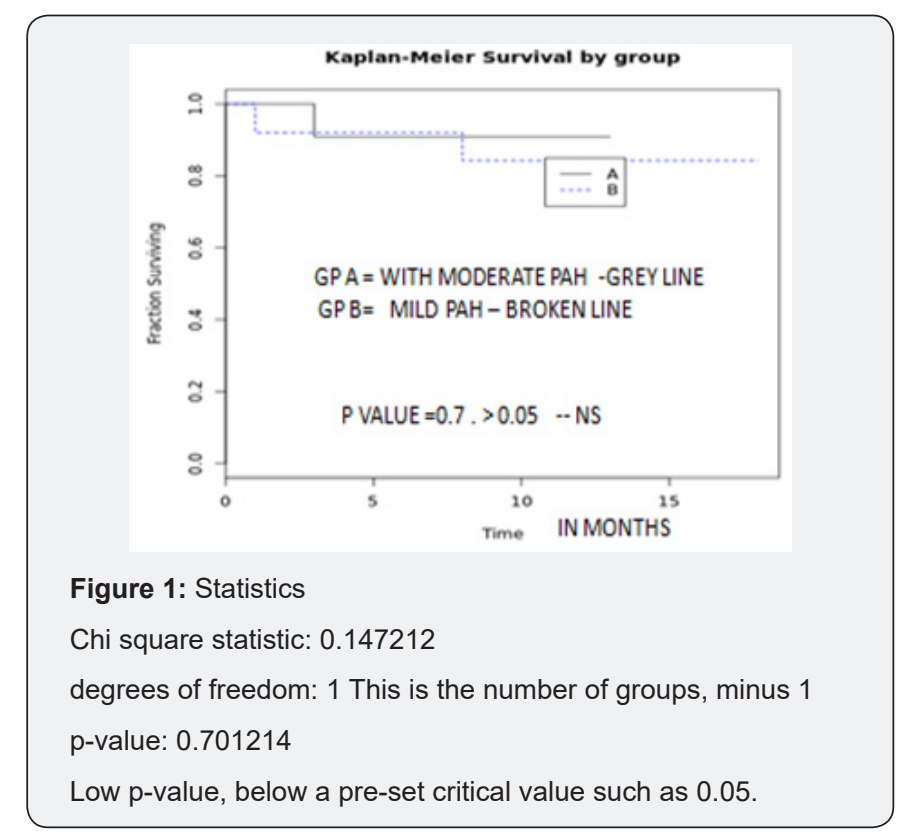




\section{Conclusion}

$30 \%$ of Patients had persistent pulmonary Hypertension one month after heart Transplant and 15\% had persistent PAH one Year after heart Transplant. But this factor does not seem to be associated with Right heart failure or reduced survival. Above Findings might have been positively influenced by Anti PAH drugs like Ambrisentan or Sildenefil given Pre-operatively.

\section{References}

1. Lindelöw B, Andersson B, Waagstein F, Bergh CH (1999) High and low pulmonary vascular resistance in heart transplant candidates. European Heart Journal 20: 148-156.
2. Ghio S, Crimi G, Pica S, Temporelli PL, Boffini M, et al. (2017) Persistent abnormalities in pulmonary arterial compliance after heart transplantation in patients with combined post-capillary and precapillary pulmonary hypertension. PLoS One 12(11): e0188383.

3. De Santo LS, Romano G, Maiello C, Buonocore M, Cefarelli M, et al. (2012) Pulmonary artery hypertension in heart transplant Recipients. How much is too much? Eur J Cardiothorac Surg 42(5): 864-869.

4. Klotz S, Wenzelburger F, Stypmann J, Welp H, Drees G, et al. (2006) Reversible Pulmonary Hypertension in Heart Transplant Candidates: to Transplant or not to transplant. Ann Thorac Surg 82(5): 1770-1773.

5. Shumway SJ, Baughman KL, Traill TA, Cameron DE, Fonger JD, et al. (1989) Persistent pulmonary hypertension after heterotopic heart transplantation: a case report. J Heart Transplant 8(5): 387-390.

\begin{tabular}{l} 
Your next submission with Juniper Publishers \\
will reach you the below assets \\
- Quality Editorial service \\
- Swift Peer Review \\
- Reprints availability \\
- E-prints Service \\
- Manuscript Podcast for convenient understanding \\
- Global attainment for your research \\
- Manuscript accessibility in different formats \\
( Pdf, E-pub, Full Text, Audio) \\
- Unceasing customer service \\
Track the below URL for one-step submission \\
https://juniperpublishers.com/online-submission.php \\
\hline
\end{tabular}

